\title{
CRITICAL ANALYSIS OF SELECTED PROVISIONS OF THE EU LEGISLATIVE PACKAGE IN RESPECT OF THE CAPITAL REQUIREMENTS FOR THE BANKING SECTOR
}

\begin{abstract}
Summary
The main aim of this article is to provide a critical analysis of selected provisions of the Directive and Regulation in respect of the capital requirements for banking and finance sector in the European Union. It focuses on the analysis of the following aspects: (i) proposed regimes, mechanisms and legal structures creating the European framework on the capital requirements; (ii) implications of the new legislation for the banking sector and for the national regulatory authorities; (iii) certain similarities between the Third Basel Accord prepared by the Basel Committee on the Banking Supervision and the proposed EU capital requirements package; and (iv) implications of the legislation for the Polish banking and finance sector.

As the global financial crisis reshaped the approach to the banking institutions throughout the world, the authorities started to be more concerned about the safety and creation of certain mechanisms preventing the sudden issues of the banks and financial institutions, which were in consequence resolved by the taxpayers. The cooperation between EU authorities and the Basel Committee on Banking Supervision resulted in the creation of the new framework on the capital requirements for the European Banking sector. To a certain extent, the EU proposal is a part of global, legal framework setting out harmonized rules ensuring the general stabilization in the banking and finance sector. It also constitutes a continuation of the EU policy on ensuring the safety of the European banking and finance sector.
\end{abstract}

Key words: Capital requirements, banking law, banking sector, financial sector, European Union, Basel Committee, financial stability, financial crisis, financial stability mechanisms.

\section{Introduction}

As a consequence of the financial crisis which triggered certain negative implications for the European banking sector, the European Union (the "EU") authorities proposed to increase the stability and further precautionary measurements to mitigate any potential risks of instability in the European banking and finance sector. In consequence, the EU Parliament, together with the EU Council, proposed new laws on, amongst other things, banking capital requirements and liquidity, namely the Capital Requirements Directive IV and the Capital Requirements Regulation (jointly referred to as the "Capital Re-

1 dr hab. Agnieszka Malarewicz-Jakubów, prof. UwB - Faculty of Law, University of Bialystok, e-mail: malarewicz@uwb.edu.pl; Paweł Kułak, Ph.D. - Faculty of Law, University of Bialystok, e-mail: paweł.kulak@gmail.com. 
quirements Package"). The proposed date of the full implementation of the Capital Requirements Package is on 1 January $2019^{2}$.

To a certain extent, the Capital Requirements Package is reflecting the new global regulatory framework agreement regarding the capital and liquidity requirements for the international banking and finance sector, prepared and proposed by the Basel Committee on the Banking Supervision (so called the "Basel IIP" or The Third Basel Accord) [The impact assessment..., 2010, p. 3].

Notwithstanding the continuation of implementing further stability mechanisms under the capital requirements regime ${ }^{3}$, the new legislation included in the Capital Requirements Package, is considered controversial from many perspectives, as it may have significant impact on the increase of costs associated with the functioning of the banking sector and the financings in general.

The purpose of this article is to perform a brief, critical analysis of the selected provisions of the new legislation regarding inter alia the capital requirements and relating to maintaining the stability in the European banking sector and to indicate certain risks associated with implementation of that new legislation. The selection of the provisions which are subject to the analysis provided hereunder was made on the basis of analysis of the financial crises that took place in the past and factors directly or indirectly causing them. These enhanced new mechanisms being the subject of the analysis provided hereunder, may - in authors' opinion - have a positive impact on maintaining the long-term stability in the European banking sector.

\section{Sanctioning regimes in the banking and finance sector}

As an aftermath of certain difficulties with the safety of funds kept by European banks and the lack of effective supervisory powers sanctioning infringement in the European banking sector, the European Commission decided to begin consultations regarding the efficient enforcement of the mechanisms ensuring the stability in the banking and finance sector [Communication from the Commission ..., 2013, p. 2]. As a result, the Commission issued a communication paper addressed to Parliament, The Council, The European Economic and Social Committee and The Committee of the Regions, in which the sanctioning regimes in the banking and finance sector, were assessed. The communication paper addresses certain inconsistencies and weaknesses of the banking and finance sector in the European Union resulting from the assessment of the sanctioning regimes in the EU Member States, carried out by the Commission in cooperation with the Committees of Supervisors [Communication from the Commission ..., 2013, p. 6].

According to the key provisions of that communication paper, sanctioning regimes in respect of the banking sector are considered to be the crucial elements in ensuring the financial stability in the sector across the European Union [Communication from the

\footnotetext{
${ }^{2}$ Information obtained from CRD IV FAQ.

3 The proposal for the capital requirements Directive IV will replace the current capital requirements directives (2006/48 and 2006/49).
} 
Commission..., 2013, p. 4]. Communication paper considers 'sanctions' as all possible actions and measures which ensure the stability across the banking and finance sector. It therefore constitutes a good starting point for the new mechanisms improving functioning of the European banking and finance sector.

As the outcome of the assessment performed under the communication paper, it was revealed that few aspects of the functioning of the banking and finance sector require certain improvements. These aspects are [Communication from the Commission..., 2013, p. 6-9]:

a) various sanctions for the same infringement of the EU laws regarding the banking and finance sector, and

b) inconsistent sanctioning mechanisms for the infringement of the EU laws regarding the banking and finance sector in respect of legal and natural persons.

The analysis performed for the purposes of the communication paper shows certain failures in functioning of the sanctioning mechanisms which have an impact on the trust and safety within the banking and finance sector. However, the assessment of issues associated with the sanctioning regimes across the EU, is only a part of a bigger reform aimed at the improvement of the safety mechanisms in the European banking and finance sector. Hence, the European Commission, taking into account the results of the sanctioning regimes assessment and the mechanisms of the Basel III agreement, initiated further steps in order to create more coherent and comprehensive framework regarding the safety in the European banking and finance sector.

\section{Analysis of the selected provisions of the Capital Requirements Directive IV}

The scope of the Capital Requirements Directive IV, is the Directive of the European Parliament and the Council on the access to the activity of credit institutions and the prudential supervision of credit institutions and investment firms and amending Directive 2002/87/EC of the European Parliament and of the Council on the supplementary supervision of credit institutions, insurance undertakings and investment firms in a financial conglomerate [Proposal for a Directive..., 2013], (the so-called the Capital Requirements Directive IV), except for the aforementioned range of various sanctioning mechanisms, covers inter alia the following crucial areas [Proposal for a Directive..., 2013, p. 2]:

a) corporate governance,

b) provisions preventing the overreliance on the credit ratings, and

c) establishment of the capital buffers (similar to those proposed in the Basel III).

As the Directive is not directly applicable, a number of prudential, directly applicable provisions are included in the Capital Requirements Regulation. However, the Directive includes more flexible and slightly broader provisions, which allow the EU Member States to have certain flexibility while implementing these provisions into their legal systems 


\subsection{Corporate governance}

As mentioned above, The Directive establishes the new legal framework for the prudential corporate governance. The source of main drivers for imposing new rules regarding the corporate governance was the aftermath of the most recent financial crisis of 2008 [The explanatory memorandum..., 2011, p. 3].

According to the report prepared by High Level Group on financial supervision in the EU, chaired by Jacquies de Larosiere [The report of the high level group..., 2009], one of the factors which caused the credit crunch was the legislation which did not prevent promotion of the policy concerning short term profits aligned with the high compensation incentive system for bankers, without consideration of the long-term consequences [The report of the high level group..., 2009, pp. 30-31]. This factor, described in the report as the corporate governance failure [The report of the high level group..., 2009, p. 31], should be addressed in the set of new rules which amongst other things, would allign the compensation schemes for the bankers with long term profits and amongst ther things, the supervision of the compensation schemes in the financial sector [The report of the high level group..., 2009, p. 31]. The Directive addresses issues pointed out in the de Larosiere report by emphasising the role and standing of the senior management of credit institutions and investment firms, the increased role of the risk management and mentioned above, sophisticated sanctioning mechanisms [The explanatory memorandum..., 2011, p. 11].

Pursuant to the provisions of the Directive, EU Member States shall ensure that the management of the credit institution implements and oversees the appropriate risk strategy, strategic objectives and controls the senior management of such institution [Directive..., 2011, Art. 88]. Additionally, the Directive points out that (unless its justified), the chairman of the management board of the credit institution cannot simultaneusly hold the position of the chief executive officer of such institution [Directive..., 2011, Art. 88]. Furthermore, the Directive includes set of professional requirements (such as skills, knowledge, experience) that the management of the credit institution and investment firm should comply with. The key provision is, that the competent public authority is entitled to monitor and and assess the institution's compliance with the corporate governance requirements set out in the Directive [Directive..., 2011, Art. 88]. As regards other corporate governance provisions, the Directive indicated rules for the remuneration of the management which should be aligned with (among other things) efficient risk management (which should not encourage the excess risk), long term interest of the institution, subject to extensive reviews.

Additionally, remuneration policies and management rules are subject to review as to their compliance with the Directive. The supervisory function regarding the compliance with these provisions is imposed on the competent institution of the EU Member State, which is obliged to request credit institutions and investment firms to take necessary measures and address (at the early stage) potential risk of not meeting the requirements of the Directive and any potential breach of rules imposed by the Directive [Directive..., 2013, Art. 102]. 


\subsection{Overreliance on the credit ratings}

The experience of the financial crisis, during which rating agencies (usually indemnified from the responsibility by the way of their cautiously drafted disclaimers) prepared many ratings highly above the real credibility of the borrower, has led the European legislators to the idea of establishing mechanisms preventing such practices. The overreliance on the credit ratings may have a significant effect on the destabilisation of the whole sector, especially when the ratings of the major rating agencies are similar [The explanatory memorandum..., 2011, p. 3]. In order to mitigate the risks associated with external credit ratings which do not reflect the actual financial standing, the EU emphasized the internal risk assessment of each institution in order to obtain a wider, more objective financial perspective on an entity. The Directive, imposes the obligation on the EU Member States, to ensure that the credit institutions develop and evaluate the internal rating-based assessment mechanisms [Directive..., 2013, Article 77]. This would complete the results of the external rating agencies assessments. In consequence, the bank making decision regarding the transaction, would be able to take the holistic view on the entity, its assets and obligations, considering external and internal ratings. Firstly, the implementation of such a mechanism will motivate independent rating agencies to perform their assessments more carefully. Secondly, the risk that the credit institution was taking while relying on the external ratings only, would be mitigated by relying also on solid, internal risk rating assessment mechanisms, that will be subject to supervision and potentially sanctions by the competent public authorities monitoring the compliance with the Directive provisions. Such protection mechanism shall lower the risk of failure in respect of financial assessment of and in consequence, shall lower the risk of non-performing loans and potentially risky exposure of the credit institution's capital.

\subsection{The establishment of capital buffers}

The concept of countercyclical capital buffers has been first introduced under the Third Basel Accord [A global regulatory framework..., 2011, p. 5]. The aim of imposing regulations regarding the capital buffers is to prevent excessive leverage and stabilise the bank's capital, despite the current cycle of the economy [The explanatory memorandum..., 2011, p. 3].

The Directive, sets out two types of the capital buffers [Directive..., 2013, Articles 128-129]:

a) capital conservation buffer, and

b) countercyclical capital buffer.

\section{Capital conservation buffer}

The Directive imposes on the EU Member States the obligation to require from the credit institutions to maintain (in addition to the common equity tier 1 capital) the specific conservation buffer of the common equity tier 1 capital, equivalent to $2.5 \%$ of 
the total capital exposure of such credit institution calculated in accordance with the Capital Requirements Regulation [Directive..., 2013, Art. 129]. In other words, the capital conservation buffer is a buffer would be based on the tier 1 assets (best quality) to ensure that the capital behind such buffer is available at all times. Such buffer should be built up in the prosperous, market high years. The aim of such buffer is to absorb losses and enable the credit institution to resist market downgrade for several years [The explanatory memorandum..., 2011, p. 12].

\section{Countercyclical capital buffer}

In addition to the capital conservation buffer, the Directive imposes on the EU Member States the obligation to require from the credit institutions, the countercyclical buffer, which shall consist of the weighted average of the countercyclical buffer rates that apply in the jurisdictions where the relevant credit exposures of the institution are located [Directive..., 2013, Article 140]. In other words, the countercyclical capital buffer is aimed at providing stability for the credit institution during the market destabilisation resulting from systemic changes (i.e. liberalisation or deliberalisation of the credit policies and any structural changes). As regards the amount of the countercyclical buffer, it will be set up by the EU Member States national authorities in relation to the loans provided in favour of the legal and natural persons. The amounts of the countercyclical capital buffer are between 0 and $2.5 \%$ of the risk weighted assets and can be set by the national authorities even beyond 2.5\% (if justified) [The explanatory memorandum..., 2011, pp. 12-13]. Funds for such buffer are collected during the market growth.

Buffers proposed under the Directive are aimed at the stabilisation of the financial sector and balancing the capital floating within such sector during the market variations. However, the funds which are gathered for the purposes of the capital buffers may increase the costs of financing. Although, it mainly depends on the way in which the Directive will be implemented, most probably funds collected for the purposes of the buffers will be compensated by the banks from the customers.

The above-analysed mechanisms included in the Directive, create numerous additional obligations on EU Member States and credit institutions/investment firms. All of them are aimed at enhancing organization and improving the supervision in the banking and finance sector. To a certain extent, the obligations imposed on Member States may imply the development of certain units within the financial supervision authorities, which will manage solely the sector's compliance and implementation of the new mechanisms. Furthermore, considering the number of regulations, the banks within their compliance departments may need to establish special units which would manage the effective implementation and monitoring the compliance with the new rules.

\section{Analysis of the Capital Requirements Regulation}

The Regulation of the European Parliament and the Council on prudential requirements for the credit institutions and investment firms (the "Regulation") is a com- 
plimentary element of the Capital Requirements Package aimed at providing further stabilization in the European banking sector. As it is directly applicable in the EU Member States, its provisions need to be clear, coherent and possible to apply in the diverse banking sectors of all EU Member States. The Regulation more than the Directive, creates so called "The Single Rule Book", which is aimed at creating organized, harmonized, including sanctions and relevant supervision mechanisms, legal framework [The executive summary..., 2011, pp. 4-5].

Amongst other things, the Regulation covers the following areas [The executive summary..., 2011, p. 5]:
a) Liquidity;
b) Leverage;
c) Regulatory capital, and
d) Counterparty credit risk.

\subsection{Liquidity}

The nationalisation of the British Northern Rock Bank is considered as the commencement of the European banking sector's liquidity crisis [The nationalisation of Northern Rock..., 2009, p. 3]. The default of the Northern Rock has started the period of issues with raising funds by banks. In consequence, such issues were partially resolved by the taxpayers under several big nationalisations, such as Nothern Rock or The Royal Bank of Scotland. In addition to the extreme cases of nationalisation, liquidity issues were being resolved ad hoc, also by interbank funding. According to the EU Commission, in few months at the end of 2008, the European Central Bank loans granted in favour of the credit institutions within the Euro Zone, have increased by $70 \%$ [The executive summary..., 2011, p. 2]. In practice, the shortage of funds as a result of liquidity issues, is usually caused by not synchronised inflows and outflows of the funds [The executive summary..., 2011, p. 8]. The experience of past years and the requirement to enhance the management of liquidity led European authorities to prepare set of rules and mechanisms aimed at ensuring the stable liquidity in the banking and finance sector.

The capital requirements regulation addresses liquidity issues by way of setting up the two following key mechanisms adopted from the Third Basel Accord:

a) Liquidity coverage ratio, and

b) Net stable funding ratio.

Liquidity coverage ratio (the "LCR"), is a measure introduced to ensure the stable liquidity of the financial institutions in a short term liquidity shortage (up to 30 days) resulting from the systemic shock and particular institution issues [The explanatory memorandum..., 2011, point 2.2.1]. The source of capital required to ensure the short term coverage would be based on the high quality (tier 1) liquid assets (such as for example cash, central bank reserves, high quality sovereign debt and potentially high quality corporate bonds and/or covered bonds) [Annex IV ..., 2011]. The liquidity coverage ratio should be implemented in 2015 and it is expected to bring gains of the EU 
GDP in the range of $0.1 \%$ to $0.5 \%$, (in consequence of the reduction of the systemic shocks) [The executive summary..., 2011, p. 4].

It appears that the liquidity coverage ratio as the measure ensuring the short term liquidity upon unexpected downturn should be backed up not by liquid securities (such as bonds) but rather by reserves in cash. However, this would create the impression that the LCR is rather a reserve fund/buffer, than a ration which in general should be a instrument separate from the buffers (also introduced by the Capital Requirements Package). It is worth mentioning that the proposed scope of the liquid "assets" backing up the LCR, should be rather flexible (construed in a form of a open catalogue) in order to leave the flexibility of choosing the asset which should be liquified for the purposes of covering the LCR, depending on the current market situation.

Net stable funding ratio (the „NSFR”) is a measure introduced to ensure liquidity during downturn in profitability or stress scenario for a period of 1 year [The impact assessment, 2011, p. 26]. According to public consultations which took place in 2010, the source of funds for the net stable funding ratio, should be [Annex $V \ldots]$ :

a) own funds eligible instruments and other liabilities $>1$ year residual term $100 \%$;

b) stable deposits of retail and small business customers (non-maturity or residual maturity < 1year);

c) less stable deposits of retail and small business customers (non-maturity or residual maturity < 1year);

d) wholesale funding provided by non-financial corporate customers (nonmaturity or residual maturity $<1$ year) $50 \%$;

e) all other liabilities and equity not included above.

The Commission intends to impose the measurements of the NSFR from 2018 [The explanatory memorandum..., 2011, p. 14] and up until then, observations of the banks practices will be procured. Considering that the NSFR is intended to provide the long term liquidity backup, the ,assets” backing up funds for these purposes are required to ensure the adequate, stable return. The results of public consultations suggest that mainly deposits and own funds should be the source for NSFR. In addition to these key elements, the return on mid-term investment grade corporate loans may be considered as the stable basis for the stable return and profits for the credit institutions.

\subsection{Leverage}

The level of credit institutions' leverage is closely related with the risk of the bank. In practice, the leverage is the percentage that represents the degree of the bank's exposure exceeding its capital [The explanatory memorandum..., 2011, p. 57]. In other words, it is considered as the amount of exposed capital of the bank versus its own capi$\mathrm{tal} /$ assets.

According to the provisions of the Regulation, the so called "exposure" is defined as "assets, off-balance sheet obligations and contingent obligations to pay or to 
deliver or to provide collateral, including obligations from received funding, made commitments, derivates or repurchase agreements, but excluding obligations which can only be enforced during the liquidation of an institution" [Regulation..., 2013 Art. 4].

Although the Regulation does not currently contain provisions setting out the standarised degree of the leverage ratio, it:

a) establishes mechanisms on the monitoring and supervisory of the level of the leverage within the European credit institutions and investment firms [The executive summary..., 2011, p. 5], and

b) contains provisions on method under which the degree of leverage should be calculated [Regulation..., 2013, Art. 429].

In order to ensure the stabilization in the European banking sector, the Capital Requirements Package should also contain binding provisions on the degree of leverage, which would allow banking institutions to have some flexibility. Hence, the degree of leverage should rather not be set at the certain level but rather as a range of percentage.

Notwithstanding the non-binding nature of current leverage ratio, it is possible that it will become binding in 2018 after its period of observation elapses [The executive summary..., 2013, p. 5]. However, it is not clear whether the imposed ratio will take the form of a threshold or a percentage range.

\subsection{Regulatory capital}

The Regulation introduces new criteria for categorizing the quality of the regulatory capital. Such new criteria built up the definition of the regulatory capital, which appears in the new regulation as Capital Tier 1 and Equity Tier 1 [The explanatory memorandum..., 2011, p. 6]. Improving the quality and harmonisation of the funds held by credit institutions and investment firms resulting from the experience of large-scale losses in the banking sector was one of the main drivers to introduce new rules regarding the quality of the capital [Regulation..., 2013, Point 53 of the preamble]. The overall crisis in the banking sector indicated weak financial instruments, such as hybrid capital instruments based on the structures containing debt and equity instruments [The executive summary..., 2011, p. 2]. Such hybrid instruments, amongst other characteristics, have an insufficient degree of loss absorption and in consequently lower the degree of trust in the markets.

In order to strengthen and harmonise corporate structures of credit institutions and investment firms, the Regulation includes provisions regarding the minimum requirements in respect of the quality and the quantity of the regulatory capital. Under the Regulation, the capital should consist of the following items [Regulation..., 2013 Article 25 and Article 62 and further]:

a) Common Equity Tier 1 capital;

b) Additional Tier 1 capital, and

c) Tier 2 capital that is equal to or less than $25 \%$ of own funds.

Pursuant to the provisions of the Regulation, 
1. Common Equity Tier 1 capital should include the following items [Regulation..., 2013, Art. 25]:

a) capital instruments, provided the conditions laid down in Article 27 and 28 (Amongst other things: the instruments are issued directly by the institution with the prior approval of the owners of the institution or, where permitted under applicable national law, the management body of the institution.) are met;

b) share premium accounts related to the instruments referred to in point (a),

c) retained earnings,

d) accumulated other comprehensive income,

e) other reserves,

f) funds for general banking risk.

2. Additional Tier 1 capital should include the following items [Regulation..., 2013, Art. 51]:

a) capital instruments, where the conditions laid down in Article 52(1) (Amongst other things: the instruments are issued and paid up, the purchase of the instruments is not funded directly or indirectly by the institution) are met,

b) share premium accounts related to the instruments referred to in point (a).

3. Tier 2 capital should include (among other things) the following items [Regulation..., 2013, Art. 62].

a) capital instruments, where the conditions laid down in Article 63 (Amongst other things: the instruments are issued and paid up, the purchase of the instruments is not funded directly or indirectly by the institution) are met,

b) the share premium accounts related to the instruments referred to in point (a).

Considering the aforementioned features, the proposed new capital requirements regime creates a quite strictly regulated framework. On the one hand, strengthening and stabilizing capital structures within the banking sector will help to avoid financial, institution-specific variations caused by the market turbulences. On the other hand, strict requirements regarding own capital and the imposed "savings" policy may have a negative impact on the potential investment activities of credit institutions and investment firms in the EU. In consequence, European credit institutions having funds limited by the capital requirements framework may be less competitive in the investment sector, in comparison with banks registered outside the $\mathrm{EU}^{4}$.

The new framework concerning the regulatory capital will not be fully implemented from the beginning. It will be monitored and gradually implemented in order to ensure that the new requirements would not destabilize the banking and finance industry and financial markets in the EU [The explanatory memorandum..., 2011, p. 6].

\subsection{Counterparty credit risk}

The global financial crisis has indicated that the regulations in respect of certain types of securities (such as so called „over-the-counter" derivatives) are not sufficient to

\footnotetext{
${ }^{4}$ And not binded by the Basel III requirements.
} 
keep the risk associated with such transactions at a relatively low level [The executive summary..., 2011, p. 3]. The difference between the bank's exposure resulting from the loan in comparison to the exposure resulting from the counterparty credit risk, is that the transaction failure has an impact on at least two parties involved therein, rather than a singular impact on the bank granting a loan [The impact assessment..., 2011, p. 56]. Therefore, a series of failed transactions on derivatives (by both parties, i.e. the party whose risk was hedged and the hedging counterparty) may have a systemic impact on the market circumstances (both for the party whose risk was hedged and the hedging counterparty).

In order to impose further regulations regarding the counterparty hedging risk, the Capital Requirements Package would impose additional capital charge for possible losses associated with the failure of the counterparty [The explanatory memorandum..., 2011, p. 6].

This capital charge - on the longer term, would enable hedged parties to retain the funds that might have been lost if the hedging counterparty has defaulted. Implementing in the Regulation the stabilisation and safety mechanisms in respect of derivatives, is an element of a bigger policy on building up the safe European derivatives market. In this respect, the Regulation is complementary with the Regulation on over-thecounter derivatives, central counterparties and trade repositories [The explanatory memorandum..., 2011, p. 26], of 15 September 2010 [Regulation (EU) No 648/2012..., 2013]. Establishment of the additional charge on the banks potentially will increase the costs of hedging transactions and in consequence the transactions in general. However, from the perspective of systemically important financial institutions, the establishment of such charge may secure the interest of parties involved in the transaction.

In addition to the provisions described above, the Regulation establishes new, harmonised supervisory legal framework [The explanatory memorandum..., 2011, p. 6]. Considering, that a number of crucial provisions has been included in the Regulation (which is directly applicable), it may have a positive impact on the harmonisation and interpretation of certain rules in all EU Member States. The aim of EU legislators drafting the Regulation was to create a comprehensive source of main rules, which are clear, coherent and easy to read and interpret. However, bearing in mind that capital requirements and other related areas are quite specific matters, at first the Regulation may appear as an encyclopaedia rather than a book. It is also worth mentioning that the purpose of creating a single rule book was to avoid situations in which national authorities would interpret certain provisions differently (in line with its own intentions, understanding), which may be deeded as promoting, the so-called "gold plating"5 of the Regulation's provisions.

${ }^{5}$ Intentional exceeding the terms of the EU legislation by the national authorities of the EU Member States. 


\section{Presumable positive and negative implications of the new EU legislation}

Criticism of independent observers and bankers relates mainly to the standarised rules for all the banks in the European banking and finance sector, despite the differences in their size and the lack of the minimum, risk limiting, binding leverage ratio [Lannoo, 2012]. The proportionality issue has been pointed out by the Parliament of the EU as one of the most important matter in the context of the "too big to fail" issue and proportionate adjustment of the regulations to the type of business, level of risk, size and the business model [European Parliament Resolution..., 2011] of the financial institution being subject to the Capital Requirements Package provisions.

As the European banking sector is rather diverse, construed as in Poland of: numerous cooperatives, commercial banks and banks being members of larger, international corporate structures, Capital Requirements Package's provisions should be applicable proportionately to the scale of risk that the banks are exposed to. On the other hand, the control mechanisms are playing quite important role in shaping the level of proportionality concept [Stępkowski, 2010, p. 230] while applying the Capital Requirements Package in the banking sector. However, at this stage the pragmatism of the supervision and control in respect of applying the new mechanisms to be implemented under the Capital Requirements Package is difficult to assess, as these provisions have not been yet exercised in practice. Notwithstanding the lack of practical assessment of the mechanisms, it should be pointed out that the Capital Requirements Package includes numerous new mechanisms which would allow the banks and the regulators to proportionately apply them for the relevant addressees.

Imposing heavy regulations, in general does not have a good impact on the development of any firm or institution as it may cause an administrative burden. However, in this particular case, the purpose of this legislation is not to ensure the free float of funds and freedom of transacting but rather to ensure the safety, control and prevention of the banking and finance sector from major stresses.

In fact all the new legal concepts introduced by the Capital Requirements Package can be analysed, among others, from four main perspectives:
a) commercial,
b) legal,
c) short-term,
d) long-term.

Many of the legal mechanisms introduced under the Capital Requirements Package (such as the capital buffers or the counterparty risk charge) impose additional costs on the banking sector and in consequence may have a short-term negative commercial impact on the number of transactions, as banks may try to transmit these costs on to the borrowers and other business parties.

However, from the long term commercial perspective, additional costs resulting from the establishment of inter alia capital buffers, may mitigate the risk of a systemic shock and a default of the credit institution, which at the end would prevent more significant losses of the business parties' capital. 
As regards the legal short term perspective, the establishment of a significant number of new rules and mechanisms may cause major challenges for national supervisory authorities in the EU Member States, the European Banking Authority and the internal compliance departments of the banks. On the other hand, for the banks performing cross-border activity within the EU, having a single rule book would help to standarise the compliance mechanisms in all EU Member States.

Despite the short term organizational challenges for the banks and supervisory authorities, the new legislation is expected to have a positive impact on the harmonization of laws regarding the safety in the European banking and finance sector. Additionally, broad supervisory prerogatives introduced by the Capital Requirements Package, would potentially prevent mismanagement and malpractices in the sector.

\section{Potential impact on the Polish banking and finance sector}

Keeping in mind the structure of the Polish banking sector (66 \% of all banks assets belong to foreign, mostly EU financial, institutions) [Nier, Nedelescu, Knight, Lindgren, 2012] the impact of the new legislation in Poland, would be to a certain extent, similar to the impact of such regulations in the other EU Member States (such as: Germany, France and other EU countries whose banks have their subsidiaries in Poland).

The scale of the potential impact of the Capital Requirements Package may depend on the transition period of the new rules [The impact assessment..., 2011, p. 49]. In case the adequate timeframe is adopted, changes may be smoothly implemented. However, if the new rules are adopted within reasonably short time, then certain increase in cost of financing or immediate cuts on the shareholders dividend payments may be applicable.

One of the factors pointed out in the International Monetary Fund's report in the light of Capital Requirements Package from the Polish perspective, was the concern as to which authority, either the Financial Supervision Authority or the Systemic Risk Board, should decide on the percentage of the capital buffers under the Directive provisions [Nier, Nedelescu, Knight, Lindgren, 2012, p. 34]. This is rather a technical matter but it emphasizes that in practice, in Poland and other EU Member States some interpretation controversies may appear in relation to the delegation of some crucial assessment prerogatives.

Furthermore, as pointed out in the Impact Assessment, the implementation and enforcement of the Capital Requirements Package provisions will increase the so-called "administrative costs" [The impact assessment..., 2011, p. 48]. On one hand, administrative costs of the implementation may be regarded as costs of financing and other services resulting from cautious saving policies.

From the perspective of emerging economy such as Polish, the short-term implications of the new regulatory framework may be at first considered as a bit tough and limiting the growth of the country's Gross Domestic Product (the "GDP"). 
According to the analysis prepared by the Basel Committee on the Banking Supervision, ensuring long term stability may reduce the probability of crisis which and in consequence may even have an impact on the growth of GDP (for example, reduction of the probability of financial crisis by 1 and may even generate a growth in GDP of 0.2 per year and in case the financial crisis have long lasting implications, gains may be larger, even between $0.6 \%$ and $1.6 \%$ of GDP p.a. [Basel Committee on the Banking Supervision..., 2010, p. 13].

In order to have a complementary view on the Polish legislation on the prudential mechanisms for the banking sector, it needs to be emphasized that Polish authorities as a consequence of the implementation of a financial stability framework, set up a banks resolution fund [Ustawa o zmianie ustawy o Bankonym Funduszu Gwarancyjnym..., 2013]. The idea of the banking resolution funds was mentioned in 2010, by the Cross Border Bank Resolution Group associated with the Basel Committee on the Banking Supervision which prepared a consultative document called "The Report and Recommendations of the Cross-border Bank Resolution Group" [Basel Committee on Banking Supervision, Report and Recommendations..., 2010, p. 6]. This report has first addressed the risks relating to the crises and potential insolvency in the banking and finance sector, which may have a negative impact on the economy of the country, region and financial situation of interconnected institutions and companies. Polish banks resolution fund was set up in order to finance the banks which are facing financial difficulties. This initiative, together with the potential implications of the Capital Requirements Package, may be considered as restrictive regulator's reply to the potential financial crises.

The Capital Requirements Package, together with Polish initiatives on setting up the resolution fund are aiming at ensuring the liquidity of the banks, understood as the ability to fulfil its financial obligations rather than ensuring the financial liquidity understood as the method to exchange the assets into funds [Uryga, Magielski, 2000, p. 48]. From the practical perspective, the later seems to be more difficult to achieve, as the external factors (such as the current economic situation of the state, amount of funds on the market, demand and supply) have impact on the level of financial liquidity.

\section{Conclusions}

The EU Capital Requirements Package is considered as well-structured (less precise provisions are included in the Directive which is required to be implemented and crucial, precise provisions are included in the Regulation which is directly applicable), coherent and comprehensive source of important institutions and mechanisms which shall ensure the harmonisation of the banking safety rules within the EU and stabilisation of the European banking. The European initiative to impose new rules on the capital requirements is a part of a bigger global policy on the financial stabilization, initiated by the Basel Committee on the Banking Supervision under the Third Basel Accord and many other international and European initiatives, such as the initiative to establish banks resolution funds. 
The current version of the European Capital Requirements Package is, to a certain extent, a continuation of the former European policy in respect of the capital adequacy within the European banking sector. Further improvements on the rules were required after the analysis of the financial crisis results. Hence, the cooperation of the EU authorities with the Basel Committee on the Banking Supervision on the global harmonization of the "safety" rules for the banking sector was required.

As presented in the above analysis, the EU Capital Requirements Package brings many changes to the legislation which was in force up until now. Some of the mechanisms and legal institutions are incorporated into the EU legislation from the Third Basel Accord and some of them were created autonomously by the EU authorities.

Under the new rules, the European banking sector will be exposed to an extensive supervision and monitoring regarding the compliance with the new legislation. This may have a positive impact on limiting the negative aspects of the functioning of the banks and financial institutions but, on the other hand, it may create a situation in which the regulators having power in their hands will be exposed to certain risks associated with the improper use of implied powers.

The overview of the new capital requirements legislation creates the impression that from the date on which the new rules are implemented, the European banking sector will be subject to heavy regulations, monitoring and certain limitations. However, the new rules are aimed at improving stabilization and safety of the banking sector and preventing the unexpected falls rather than improving the profitability of the banking and finance sector. In the current market situation, such rules may create a good environment for sustainable development of the European economies instead of rapid growth of the banking sector.

Capital Requirements Package has been passed by the relevant European authorities on 26 June 2013. Regulation is effective upon the entry into force and the provisions of Directive will be gradually implemented into the legal frameworks of the EU Member States.

\section{Bibliography}

Annex IV to the impact assessment accompanying the proposal for a Regulation of the European Parliament and the Council on prudential requirements for the credit institutions and investment firms, electronic document: [www.europa.eu, date of access: 27.05.2013].

Annex $V$ to the impact assessment accompanying the proposal for a Regulation of the European Parliament and the Council on prudential requirements for the credit institutions and investment firms, electronic document: [www.europa.eu, date of access: 27.05.2013].

Basel Committee on the Banking Supervision, An Assessment of the Long-Term Economic Impact of Stronger Capital and Liquidity Requirements, electronic document: www.bis.org/publ/ bcbs173.htm, date of access: 01.06.2013].

Basel Committee on the Banking Supervision, Basel III: A Global Regulatory Framework for More Resilient Banks and Banking Systems, electronic document: [www.bis.org/publ/ bcbs189. htm, date of access: 02.06.2013]. 
Communication from the Commission to the European Parliament, the Council, the European Economic and Social Committee and the Committee of the Regions, 2013 European Semester: Country-Specific Recommendations Moving Europe beyond the Crisis, electronic document: [http://ec.europa.eu/europe2020/pdf/nd/2013eccomm_en.pdf, date of access: 01.06.2013].

Directive of the European Parliament and of the Council on the Access to the Activity of Credit Institutions and the Prudential Supervision of Credit Institutions and Investment Firms and Amending Directive 2002/87/EC of the European Parliament and of the Council on the Supplementary Supervision of Credit Institutions, Insurance Undertakings and Investment Firms in a Financial Conglomerate, electronic document: [www.europa.eu, date of access: 02.01.2014].

Lannoo K. Europe Needs to Flex its Muscles with Banks, "Financial Times", electronic document: [www.ft.com/intl/cms/s/0/02c7968a-41c3-11e1-a58600144feab49a.html \#axzz2Usk2nnCa, date of access: 31.05.2013].

Nier E., Nedelescu O., Knight D., Lindgren C. 2012 The Report: Republic of Poland: Technical Assistance Report - Macroprudential Framework, International Monetary Fund, electronic document: [http://www.imf.org/external/pubs/ft/scr/2012/cr12276.pdf, date of access: 20.06.2013].

Proposal for a Directive of the European Parliament and of the Council on the Access to the Activity of Credit Institutions and the Prudential Supervision of Credit Institutions and Investment Firms and Amending Directive 2002/87/EC of the European Parliament and of the Council on the Supplementary Supervision of Credit Institutions, Insurance Undertakings and Investment Firms in a Financial Conglomerate, electronic document: [www.europa.eu, date of access: 29.05.2013].

Proposal for a Regulation of the European Parliament and the Council on Prudential Requirements for the Credit Institutions and Investment Firms, electronic document: [www.europa.eu, date of access: 27.05.2013].

Regulation (EU) No 648/2012 of the European Parliament and of the Council of 4 July 2012 on OTC Derivatives, Central Counterparties and Trade Repositories, electronic document: [www.europa.eu, date of access: 01.06.2013].

Regulation of the European Parliament and the Council on Prudential Requirements for the Credit Institutions and Investment Firms, electronic document: [www.europa.eu, date of access: 02.01.2014].

Resolution of the European Parliament of 7 October 2010 on Basel II and Revision of the Capital Requirements Directives (CRD 4) (2010/2074(INI)), Official Journal of the EU 2011/C $371 \mathrm{E} / 05$, electronic document: [www.europa.eu, date of access: 17.06.2014].

Stępkowski A. 2010 Zasada proporcjonalności w europejskiej kulturze prawnej, Liber, Warszawa. The Executive Summary of the Impact Assessment Accompanying Proposal for a Directive of the European Parliament and the Council on the Access to the Activity of Credit Institutions and the Prudential Supervision of Credit Institutions and Investment Firms and Amending Directive 2002/87/EC of the European Parliament and of the Council on the Supplementary Supervision of Credit Institutions, Insurance Undertakings and Investment Firms in a Financial Conglomerate, electronic document: [www.europa.eu, date of access: 27.05.2013]. 
The Executive Summary of the Impact Assessment Accompanying the Proposal for a Regulation of the European Parliament and the Council on Prudential Requirements for the Credit Institutions and Investment Firms, electronic document: www.europa.eu, date of access: 27.05.2013].

The Explanatory Memorandum to a Proposed Directive of the European Parliament and of the Council on the Access to the Activity of Credit Institutions and the Prudential Supervision of Credit Institutions and Investment Firms and Amending Directive 2002/87/EC of the European Parliament and of the Council on the Supplementary Supervision of Credit Institutions, Insurance Undertakings and Investment Firms in a Financial Conglomerate, electronic document: [www.europa.eu, date of access: 29.05.2013].

The Explanatory Memorandum to a Proposed Regulation of the European Parliament and the Council on Prudential Requirements for the Credit Institutions and Investment Firms, electronic document: [www.europa.eu, date of access: 27.05.2013].

The Impact Assessment Accompanying Proposal for a Directive of the European Parliament and the Council on the Access to the Activity of Credit Institutions and the Prudential Supervision of Credit Institutions and Investment Firms and Amending Directive 2002/87/EC of the European Parliament and of the Council on the Supplementary Supervision of Credit Institutions, Insurance Undertakings and Investment Firms in a Financial Conglomerate, electronic document: [www.europa.eu, date of access: 27.05.2013].

The Impact Assessment Accompanying the Proposal for a Regulation of the European Parliament and the Council on Prudential Requirements for the Credit Institutions and Investment Firms, electronic document: [www.europa.eu, date of access: 27.05.2013].

The Nationalisation of Northern Rock, 31st Report of Session 2008-09, House of Commons, Public Accounts Committee, Published on 25 June 2009, electronic document: [www.voltairenet.org/IMG/pdf/Nationalisation_of_Northern_Rock.pdf, date of access: 01.06.2013].

The Report of Basel Commitee on Banking Supervision, Report and Recommendations of the Crossborder Bank Resolution Group, published by teh Bank for International Settlements in March 2010, electronic document: [http://www.bis.org/publ/bcbs 169.pdf, date of access: 18.06.2014].

The Report of the High Level Group on Financial Supervision in the EU (so called the de Larosiere report), Brussels 2009, electronic document: [http://ec.europa.eu/internal_market/ finances/docs/de_larosiere_report_en.pdf, date of access: 01.06.2013].

Uryga J., Magielski W. 2000, Bankouy Plan Kont, Interfin, Kraków.

Ustawa z dnia 26 lipca 2013 r. o zmianie ustany o Bankouym Funduszu Gwarancyjnym oraz niek.tórych innych ustaw, Dz. U. 2013 poz. 1012. 